\title{
SEMI-AUTOMATED CLASSIFICATION OF LANDFORM ELEMENTS IN ARMENIA BASED ON SRTM DEM USING K-MEANS UNSUPERVISED CLASSIFICATION
}

\author{
Artak Piloyan ${ }^{1}$, Milan KoneČnÝ ${ }^{2}$ \\ ${ }^{1}$ Faculty of Geography and Geology, Yerevan State University, Armenia \\ ${ }^{2}$ Department of Geography, Faculty of Science, Masaryk University, Brno
}

Manuscript received: January 12, 2017

Revised version: February 3, 2017

\begin{abstract}
Piloyan A., Konečný M., 2017. Semi-automated classification of landform elements in Armenia based on SRTM DEM using k-means unsupervised classification. Quaestiones Geographicae 36(1), Bogucki Wydawnictwo Naukowe, Poznań, pp. 93-103, 5 figs, 4 tables.

ABSTRACT: Land elements have been used as basic landform descriptors in many science disciplines, including soil mapping, vegetation mapping, and landscape ecology. This paper presents a semi-automatic method based on k-means unsupervised classification to analyze geomorphometric features as landform elements in Armenia. First, several data layers were derived from DEM: elevation, slope, profile curvature, plan curvature and flow path length. Then, k-means algorithm has been used for classifying landform elements based on these morphomertic parameters. The classification has seven landform classes. Overall, landform classification is performed in the form of a three-level hierarchical scheme. The resulting map reflects the general topography and landform character of Armenia.
\end{abstract}

Corresponding author:artakpiloyan@ysu.am

\section{Introduction}

Information about landforms is crucial, for instance, for studies of landscape evaluation and, assessment of potential erosion, natural hazards and risk prediction, as well as for regional planning of landscapes, cadastral assessment of land use etc. The classical ways to implement (combine) relief units on landscape assessment is to delineate them during ground truthing and/or by using aerial photographs. Such an approach is relatively time consuming and the results are largely dependent on the researcher's subjective assessment and, therefore, in many cases they may not have sufficient transparency and reproducibility (Dragut, Blaschke 2006). Terrain analysis in environmental assessments of landscape was quite rare until the last decade, while terrain topography is a key indicator in a wide range of environmental processes (Bates et al. 1998, Butler 2001). Nevertheless, such a landscape approach is an important step in a variety of regional studies (Dragut, Blaschke 2006). Particularly, landscape pattern could have a crucial influence on the spread of disturbance (Turner 1990, Forman 1995, Butler 2001), water quality (Hunsaker et al. 1992, Arakelyan, Piloyan 2011), environmental quality and biodiversity (Gordon et al. 1994), as well as substantiate the mechanisms of material flow (Dalrymple et al. 1968).

Terrain analysis is the set of activities which leads to the compilation of terrain characteristics or 
terrain qualities (Townshend 1981). Automated and semi-automated terrain analysis from the Digital Elevation Models (DEM) has become widely used in geomorphological researches and landform classifications during recent years. Landform features as physical constituents of terrain has been extracted from DEMs using various approaches including combination of geomorphometric parameters (Dikau 1989, Iwahashi, Pike 2007), fuzzy logic and unsupervised classification (Irvin et al. 1997, Burrough et al. 2000, Adediran et al. 2004), supervised classification (Brown et al. 1998, Hengl, Rossiter 2003, Prima et al. 2006), probabilistic clustering algorithms (Stepinski, Vilalta 2005), multivariate descriptive statistics (Evans 1972, Dikau 1989, Dehn et al. 2001), double ternary diagram classification (Crevenna et al. 2005), object-oriented image analysis (Dragut, Blaschke 2006) and artificial neural networks (Ehsani, Quiel 2008).

The aim of this paper is to perform landform classification via k-means unsupervised classification of geomorphometric parameters computed from the SRTM DEM of the territory of Armenia.

\section{Material and Methods}

\section{Geomorphometric parameters}

Elevation, slope, plan and profile curvatures according to Evans (1972) and Shary (1995, Shary et al. 2002) schemas and the flow path length according to Horton method (Horton 1945, Mitasova, Hofierka 1993, Zavoianu et al. 2013) were used as a DEM-based geomorphometric layers for semi-automated landform classification of the territory of Armenia. Evans (1972), Lastochkin (1991), and Simonov (1999) point out that elevation, slope and aspect are compulsory for every kind of geomorphometric analysis. But for solving a number of geomorphological and geo-ecological issues plan and profile curvatures are also necessary. Plan curvature is a measure of flow convergence $(\mathrm{kh}<0)$ and divergence $(\mathrm{kh}$ $>0$ ) and determines soil water or the deposition of particles. Profile curvature controls water flow acceleration $(\mathrm{kh}>0)$ and deceleration $(\mathrm{kh}<0)$ and therefore the erosion potential of an area (Shary 1995, Shary et al. 2002, Schillaci et al. 2015). For both parameters units are expressed in $1 / \mathrm{m}$. The effectiveness of the flow path length maps is also undisputed, because this parameter is a component for many empirical equations for calculation of surface erosion (Zavoianu et al. 2013).

\section{Digital Elevation Model}

To perform terrain analysis a DEM containing information about relief morphology in sufficient accuracy is very useful. During the last two decades the availability of DEM data has been continuously growing. The most common freely available global DEMs are SRTM (Shuttle Radar Topographic Mission) with $90 \mathrm{~m}$ and $30 \mathrm{~m}$ spatial resolution (Rabus et al. 2003, Berry et al. 2007, Farr et al. 2007) and ASTER GDEM (Advanced Spaceborne Thermal Emission and Reflection Radiometer/Global Digital Elevation Model) with $30 \mathrm{~m}$ spatial resolution (Hayakawa et al. 2008). SRTM DEM provides an essentially constant quality, while the quality of ASTER DEM is uneven (Crippen et al. 2007, Huggel et al. 2008). This difference is partly due to the wavelengths used in these models. The ASTER sensor works in the near infrared bandwidth which is disturbed by cloud coverage, while the SRTM works with microwave frequencies which are not affected by clouds (Stevens et al. 2004, Hubbard et al. 2007).

SRTM DEM with $90 \mathrm{~m}$ spatial resolution reduces the possibilities for study of small elements of relief, large elements are represented properly (Wright et al. 2006, Dragut, Eisank 2012), which in our opinion is sufficient for a terrain analysis covering the whole territory of Armenia. For this reason our analysis is based on the SRTM elevation dataset.

SRTM consisted of a specially modified radar system that flew on board the Space Shuttle Endeavour during 11 days in February 2000. SRTM utilized the dual Space-borne Imaging Radar (SIR-C) and dual X-band Synthetic Aperture Radar (X-SAR) configured as a baseline interferometer, acquiring two images at the same time, which could produce a DEM (Rodriguez et al. 2005). Many researchers used SRTM data for applications such as analysis of terrain characteristics (Rabus et al. 2003, Falorni et al. 2005) including volcanic morphology and large aeolian bedforms (Wright et al. 2006, Blumberg 2006), vegetation studies (Kellndorfer et al. 2004), 
hydrologic modelling (Ludwig, Schneider 2006), morphotectonic analysis (Grohmann et al. 2006) and identification of circular structures of terrain (Piloyan, Avagyan 2016).

\section{Software}

Extraction of geomorphometric parameters and all the analyses in this article were performed in the open source SAGA GIS, version 2.12 a software package licensed under the General Public License (GNU) and software called Whitebox GAT (Geospatial Analysis Tools) version 2.2 Iguazu, developed by Lindsay (2014). ESRI ArcGIS, version 10.2 was used for map design and presentation.

\section{K-means unsupervised classification algorithm}

Historically it so happened that the k-means algorithm was discovered by several researchers: first of all by Steinhaus (1956) and the same time by Lloyd $(1957,1982)$, but it has received wide recognition especially after McQueen's (1967) work. The initial aim of the k-means approach was the reduction of data value to support the transfer of information in the area of pattern recognition (Bezdek 1981).

K-means algorithm is one of the simplest and well known clustering algorithms. This algorithm determines the cluster centers and the elements belonging to them by minimizing the squared error based objective function. The aim of the algorithm is to locate the cluster centers as much as possible far away from each other and to associate each data point to the nearest cluster center. Euclidean distance is usually used as the dissimilarity measure in k-means algorithm. The objective function $J$ is described as follows:

$$
J=\sum_{j=1}^{k} \sum_{i=1}^{N}\left\|x_{i}^{(j)}-c_{j}\right\|^{2}
$$

where $\left\|x_{i}^{(j)}-c_{j}\right\|^{2}$ is a chosen distance measure between a data point $x_{i}^{(j)}$ and the cluster centre $c_{j}$, is an indicator of the distance of the $N$ data points from their respective cluster centres (Orhan et al. 2008).

It should be emphasized that k-means algorithm historically is one of the most important data mining algorithms. We are not the first who use k-means or its soft version fuzzy k-means algorithms to classify geospatial phenomenon. It has been successfully used in geohydrology, soil science and vegetation mapping (Vriend et al. 1988, de Bruin, Stein 1998, Burrough. McDonnell 1998, Burrough et al. 2000, 2001, Schmidt, Hewitt 2004).

Selected terrain parameters (elevation, slope, plan and profile curvature and flow path length) were treated as a single band images and using a k-mean unsupervised algorithm in the Whitebox GAT 2.2 software, the landforms were classified. K-means uses an iterative procedure that finds statistically similar groups in multi spectral space during its analysis. The algorithm starts by randomly locating $\mathrm{k}$ clusters in spectral space (Burrough et al. 2000, Moravej et al. 2012). Each pixel in the input image group is then assigned to the nearest cluster centre and the cluster centre locations are moved to the average of their class values. This classification is then repeated until a stopping condition is reached. It is supposed that no two clusters have the same cluster representative. In the case that two cluster centers coincide, a cluster center should be perturbed to avoid coincidence in the iterative process (Chang et al. 2011). The stopping condition may either be a maximum number of iterations or a tolerance threshold which designates the smallest possible distance to move cluster centers before stopping the iterative process (Moravej et al. 2012). In our case, the determinative parameters were 7,25 and $2 \%$ respectively, for the number of predictive classes, maximum iteration and pixel class change tolerance.

\section{Case Study}

A typical characteristic of the hypsometry of the territory of Armenia is a sequence of four major geomorphological provinces (from north to south) which are different in origins and altitude statistics: Those provinces are 1) The Province of Northern Fold-block Ranges and Intermountain Valleys, 2) The Volcanic Highland, 3) The Province of Southern Fold-block Ranges and Intermountain Valleys and 4) Middle Araks Depression (Fig. 1).

Based on the hypsometric curve, we can say that the territory of Armenia is a medium-altitude 


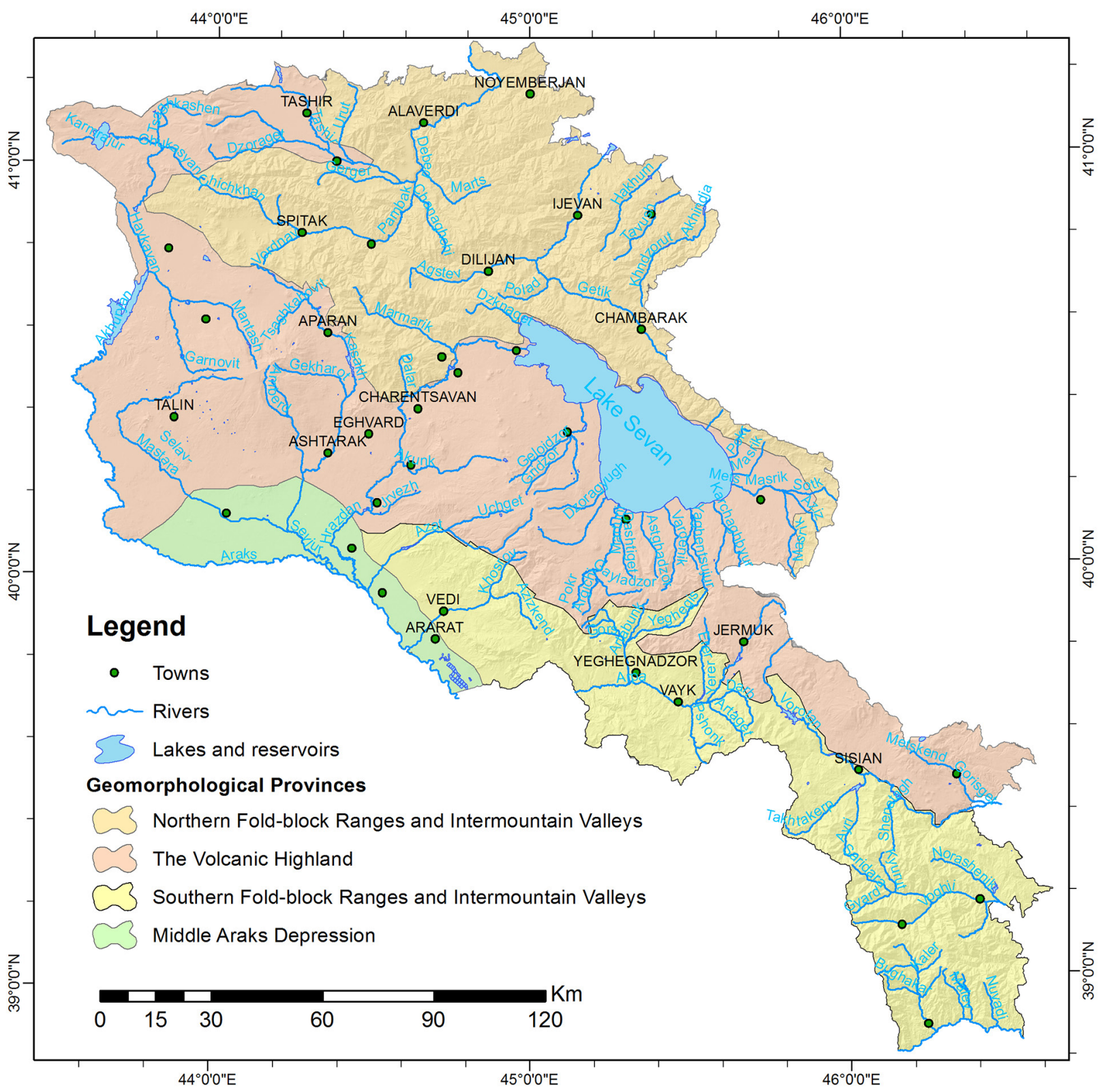

Fig. 1. Map of the geomorphological provinces of Armenia.

mountainous country dominated by absolute altitudes of 1300-2500 m (Fig. 2). Visual analysis of the hypsometric curve shows that $10.49 \%$ of the territory of Armenia is situated at altitudes up to $1000 \mathrm{~m}$, and almost half (47.84 \%) - from 1000 to $2000 \mathrm{~m}$. Only $14.41 \%$ of the total territory is above $2500 \mathrm{~m}$ (Avagyan et al. 2010). According to orographic and morphographic zones (nomenclature according to Zohrabyan 1979) the territory of the Republic is divided as follows: $68.23 \%$ of the area is occupied by high and medium mountains $(1500-2500 \mathrm{~m})$ and more than a quarter $(28.56 \%)$ by low mountains (500-1500 m). Extreme altitudes constitute only small areas: $3.21 \%$ are the highest peaks and summits of highest ranges and only $0.12 \%$ of Armenia is below $500 \mathrm{~m}$. The highest point in the territory of Armenia is the northern peak of the mount Aragats - 4090 m, and no point is below $390 \mathrm{~m}$ : the lowest points are in the valley of the Araks River at the state border with Iran. The average elevation of the territory is 1853 m (Avagyan et al. 2010).

It is worth mentioning that hypsometry of foldblock mountains usually develops by neotectonic (Late Neogene - Quaternary) movements which are differentiated in Armenia. Within the individual blocks of the Earth's crust, they are expressed by different degrees of intensity and different 


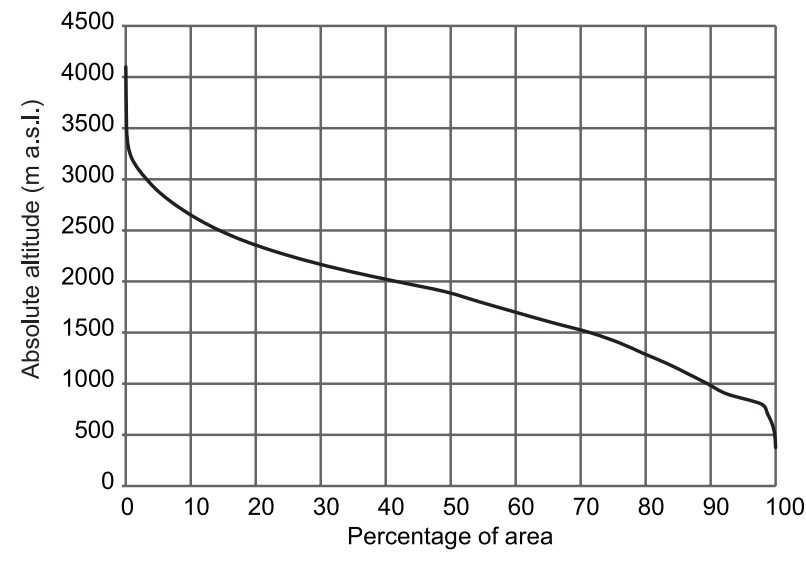

Fig. 2. Percentage hypsometric curve of the territory of Armenia.

amplitudes. This phenomenon creates various elevation levels of young mountain relief. During the formation of this neovolcanic (Quaternary) relief, along with the neotectonic movements lavas and tuff were deposited. However, in the territory of Armenia, their thickness is no more than a few hundred meters. For this reason, the main hypsometric levels in volcanic relief basically repeat the hypsometry of the relief below the lava cover (Zohrabyan 1979).

The relief of Armenia has repeatedly served as an object for morphological delineation, both alone and as part of larger spatial units. This is evidenced by the relief zoning schemes by Balyan (1969), Gevorgyan, Poghosyan (1970), Zohrabyan (1979), Boynagryan (2007). Most authors recognize that interzonal landscape differentiation is significant. Often the decisive role belongs to the geological and geomorphological factors, which are in fact non-zonal factors. This phenomenon is particularly noticeable at the lower levels of landscape classification, where the location factor is a decisive criterion for the identification of such taxonomic units as landforms (Isachenko 1991).

As landforms forma conjugate system of facies that is combined by the general orientation of physico-geographical processes, they are most clearly expressed in the conditions of classified relief with alternating convex and concave shapes of mesorelief, such as summits and hollows, ridges and depressions, shoulder slopes and footslopes, gullies and ravines, etc.

The relief of most of the territory of Armenia is a succession of such meso forms. The provinces of Northern and Southern Fold-block Ranges and Intermountain Valleys and most part of The Volcanic Highland are alternations of valleys, ridges, crests, summits, passes, channels, pits, hollows and other geomorphological middle level forms.

\section{Landform Classification}

There are many approaches and classification schemes for the landform classification in digital geomorphology (Pennock et al. 1987, Dikau 1989, Wood 1996, Irvin et al. 1997, Ventura, Irvin 2000, Macmillan et al. 2000, Burrough et al. 2001, Shary et al. 2002, Schmidt, Hewitt 2004, Dragut, Blaschke 2006, Ehsani, Quiel 2008, MacMillan, Shary 2009). Here a combination of the classification criterias of Dikau (1989), and Dragut, Blaschke (2006) with small modifications is used. And to determine a landform classes we were mainly focused on the landform classification scheme of Ventura, Irvin (2000). As noted, the following spatial layers of preliminary information were used for landform classification: altitude, plan curvature, profile curvature, slope and an additional layer flow path length. Table 1 gives the basic statistical information for these parameters and Table 2 their correlation matrix.

Table 1. Statistics of geomorphometric parameters.

\begin{tabular}{|l|c|c|c|c|}
\hline $\begin{array}{c}\text { Geomorphometric } \\
\text { parameter }\end{array}$ & Min & Mean & Max & SD \\
\hline Altitude [m] & 371 & 1852 & 4054 & 604 \\
\hline Flow path length $[\mathrm{m}]$ & 0 & 2534 & 33411 & 3061 \\
\hline Plan curvature $[1 / \mathrm{m}]$ & -3.07 & 0.0057 & 3.43 & 0.23 \\
\hline Profile curvature $[1 / \mathrm{m}]$ & -4.17 & 0.0062 & 4.1 & 0.19 \\
\hline Slope $\left[{ }^{\circ}\right]$ & 0 & 11.1 & 65.1 & 8.6 \\
\hline
\end{tabular}

Table 2. Correlation matrix of geomorphometric parameters.

\begin{tabular}{|l|c|c|c|c|c|}
\hline \multicolumn{1}{|c|}{ Geomorphometric parameter } & Altitude & Flow path length & Plan curvature & Profile curvature & Slope \\
\hline Altitude & 1 & - & - & - & - \\
\hline Flow path length & 0.022 & 1 & - & - & - \\
\hline Plan curvature & 0.033 & -0.030 & 1 & - & - \\
\hline Profile curvature & -0.079 & 0.033 & -0.449 & 1 & - \\
\hline Slope & 0.235 & -0.212 & 0.051 & 0.000 & 1 \\
\hline
\end{tabular}


It is worth mentioning that aspect have not been included in basic information sources in spite of the fact that it is an important derivative of elevation (Evans 1972). The reason for not using is that ... aspect produces additional zonation, for instance when the aspect of hillslopes changes from south to west or north to east. This zonation makes the outputs too confusing. Moreover, north-facing slopes are artificially split due to the great difference between

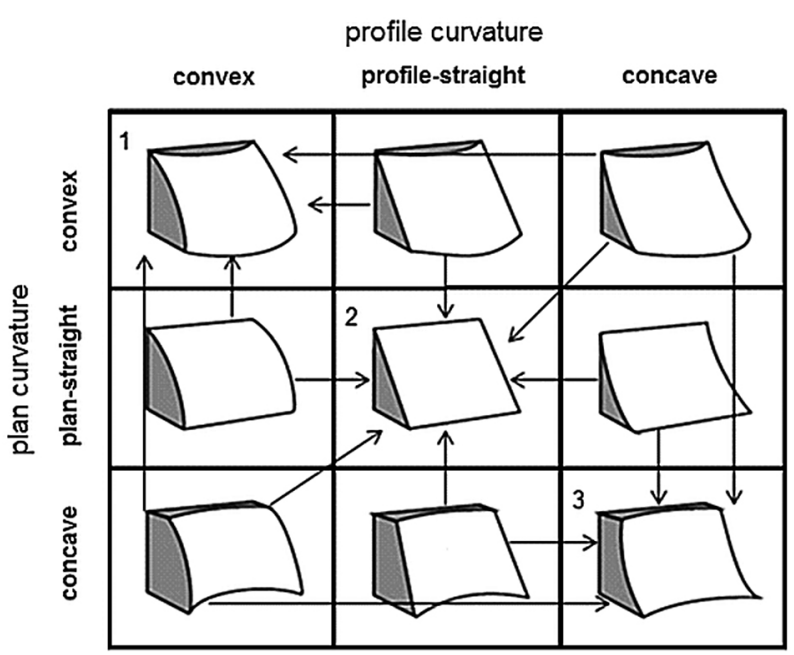

Fig. 3. Fundamental local landform elements based on plan and profile curvatures.

1 - "shoulders", 2 - "backslopes", 3 - "footslopes". Arrows indicate possible combinations in classification (modified after Dikau 1989). pixel values (e.g. 1 and 360 ) (Dragut, Blaschke 2006). But information about the aspect could easily be utilized for specific geoecological and geomorphological studies, in particular, in the evaluation of potential erosion, slope stability assessment, identification of the linear and circular morphostructures.

Dikau (1989) distinguished nine landform classes based on combinations of convex, straight and concave profiles (Fig. 3). In theory these are all possible combinations of landform classes which can be derived from the values of plan and profile curvature. However, three of these classes occur more frequently than the others in real relief. Those three classes are: "shoulder" convex element between summit and backslope, "backslope" - the typically linear, inclined part of hillslope and "footslope" - the concave part of the hillslope that welds the linear segments to lower terrain and is both an erosional and depositional surface. Taking into account the resolution of the preliminary DEM and the territory of case study the other six classes have been attached with different possible degrees of membership to one or more of the main classes (as shown by arrows in Fig. 3)

However, it is clear that landform classification based only on a curvature values would be incomplete. In the methodology of Dragut,

Table 3. Geomorphometric parameters used in landform classification.

\begin{tabular}{|c|c|c|c|c|c|c|c|}
\hline \multirow{3}{*}{ No. } & \multicolumn{2}{|r|}{ Landform element } & \multicolumn{5}{|c|}{ Geomorphometric parameter } \\
\hline & \multirow[t]{2}{*}{ Name } & \multirow{2}{*}{ Description } & Altitude & $\begin{array}{l}\text { Flow path } \\
\text { length }\end{array}$ & $\begin{array}{c}\text { Plan } \\
\text { curvature }\end{array}$ & $\begin{array}{l}\text { Profile } \\
\text { curvature }\end{array}$ & \multirow{2}{*}{$\begin{array}{c}\text { Slope } \\
{\left[{ }^{\circ}\right]}\end{array}$} \\
\hline & & & \multicolumn{2}{|c|}{$[\mathrm{m}]$} & \multicolumn{2}{|c|}{$[1 / \mathrm{m}]$} & \\
\hline 1 & $\begin{array}{l}\text { Summits, } \\
\text { Ridges }\end{array}$ & $\begin{array}{l}\text { An upland surface with an incli- } \\
\text { nation which differs distinctly } \\
\text { from the hillslope which ascends } \\
\text { to it }\end{array}$ & $\begin{array}{l}\text { Higher than } \\
\text { neighbors }\end{array}$ & $<500$ & ND & ND & ND \\
\hline 2 & $\begin{array}{l}\text { Cliffs, Steep } \\
\text { slopes }\end{array}$ & $\begin{array}{l}\text { Surface areas with slope gradient } \\
\text { higher than } 35^{\circ}\end{array}$ & ND & ND & ND & ND & $>35^{\circ}$ \\
\hline 3 & Shoulders & $\begin{array}{l}\text { Convex element between sum- } \\
\text { mits and backslope }\end{array}$ & ND & ND & + & + & ND \\
\hline 4 & Backslopes & $\begin{array}{l}\text { The typically linear, inclined part } \\
\text { of hillslope }\end{array}$ & ND & ND & \pm 0 & \pm 0 & ND \\
\hline 5 & Footslopes & $\begin{array}{l}\text { The concave part of the hillslope } \\
\text { that welds the linear segments to } \\
\text { lower terrain and is both an ero- } \\
\text { sional and depositional surface }\end{array}$ & ND & ND & - & - & ND \\
\hline 6 & Toeslopes & $\begin{array}{l}\text { The region which extends away } \\
\text { from the base of the hillslope and } \\
\text { composed of depositional debris }\end{array}$ & $\begin{array}{c}\text { Lower than } \\
\text { neighbor slopes }\end{array}$ & ND & ND & ND & $<2^{\circ}$ \\
\hline 7 & $\begin{array}{l}\text { Flat areas, } \\
\text { Floodplains }\end{array}$ & $\begin{array}{l}\text { Surface areas with slope gradient } \\
\text { less than } 2^{\circ}\end{array}$ & ND & ND & ND & ND & $<2^{\circ}$ \\
\hline
\end{tabular}


Blaschke (2006) Dikau-based classes are combined with another four, irrespective of curvature values which were derived from slope gradient and an additional parameter, a local dominance criterion. In our approach, as an additional parameter we used the value of flow path length, which is essentially close to relative altitudes, but easier to derive from elevation. Areas and relief elements for which the value of flow path length is $500 \mathrm{~m}$ and less and are situated higher than the neighbours are defined as "summits" and "ridges". Parts of slopes which are lower than the neighbour slopes are "toeslopes". The areas with slope gradient less than $2^{\circ}$ are defined as "flat areas", "floodplains", while higher than $35^{\circ}$ as "cliffs" and "steep slopes". The last two classes are the only which were classified based on constant values. Thus, the result was seven landform classes (Table 3).

The seven classes represented in Table 3 are structured in a hierarchy and grouped into similar groups. Overall, landform classification is performed in the form of a three-level hierarchical scheme (Fig. 4). On the first level they are distinguished according to altitudinal zonation (Zohrabyan 1979): Lower Mountain Zone (<1500

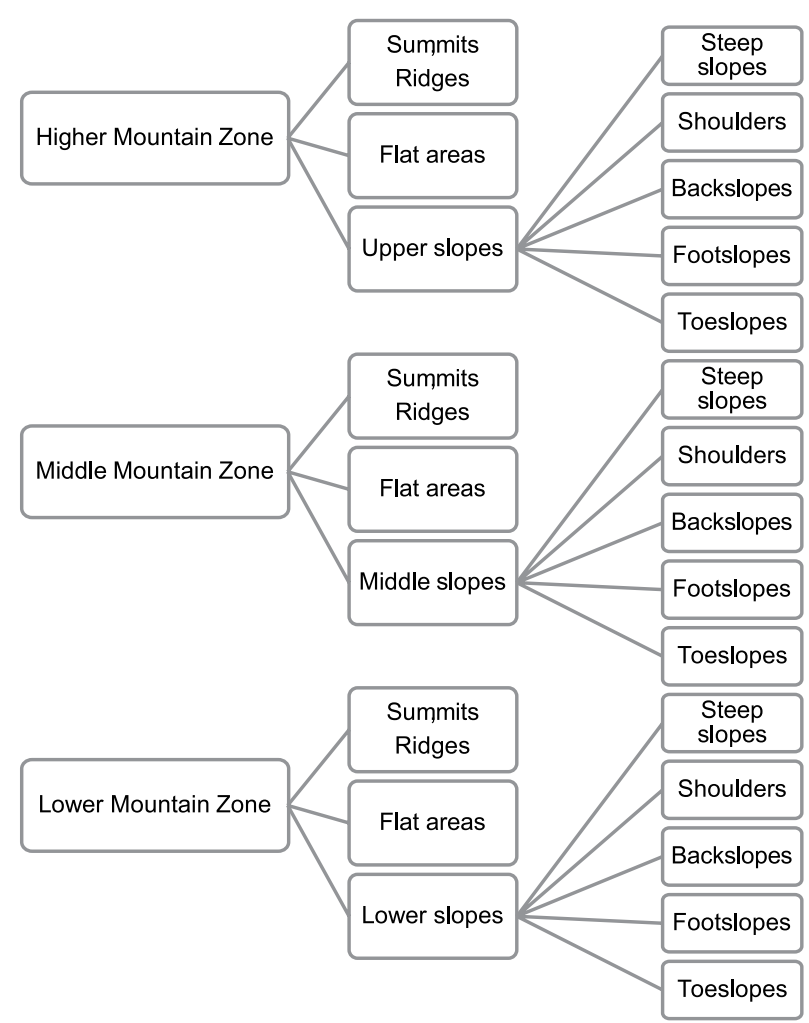

Fig. 4. Landform class hierarchy. m), Middle Mountain Zone (1500-2500 m) and Higher Mountain Zone (>2500 m).

On the middle level of the class hierarchy classification was performed according to slope mesorelief elements: These elements are: "summits" and ridges, "flat areas" and the actual slope. It should be noted that on this level, for instance, the "summits" are separated not only in the Higher Mountain Zone, but also in the others, where they can be expressed on the relief as a tops of local small hills. The same logic applies also for the flat areas.

Finally on the last level, only slopes from the second level were classified. The classes are five: "cliffs" and "steep slopes", "shoulders", "backslopes", "footslopes", "toeslopes".

\section{Results}

Thus, k-means unsupervised classification methodology has been used for classifying landform elements from DEM of Armenia, based on morphomertic parameters of relief (Fig. 5). The resulting map reflects the general topography and landform character of the territory. The advantage of the approach is that it not only produces a landform classification, but the final map can also be used to measure the uncertainty in the classification. The method is simple with respect to computational and parameter requirements and is therefore easy to apply. However, it should be mentioned, that the results of DEM processing are difficult to quantitatively verify because of the lack, at this stage of the research, of ground truth data for geomorphologic features beyond altitude.

Visual analysis of the map obtained through classification shows that "peaks", "steep slopes" and "flats" have been most clearly distinguished, which is logical, given the fact that they have been classified based on constant threshold values (Table 3).

Table 4 presents the percentage frequency of the spatial distribution of landforms in mountain zones for the whole territory of Armenia. The fact that "footslopes", "backslopes" and "shoulders" are the dominant forms indicates the erosion-fragmented nature of relief, which is characterized by the alternation of concave and convex forms of relief. Steep slopes are mainly situated 


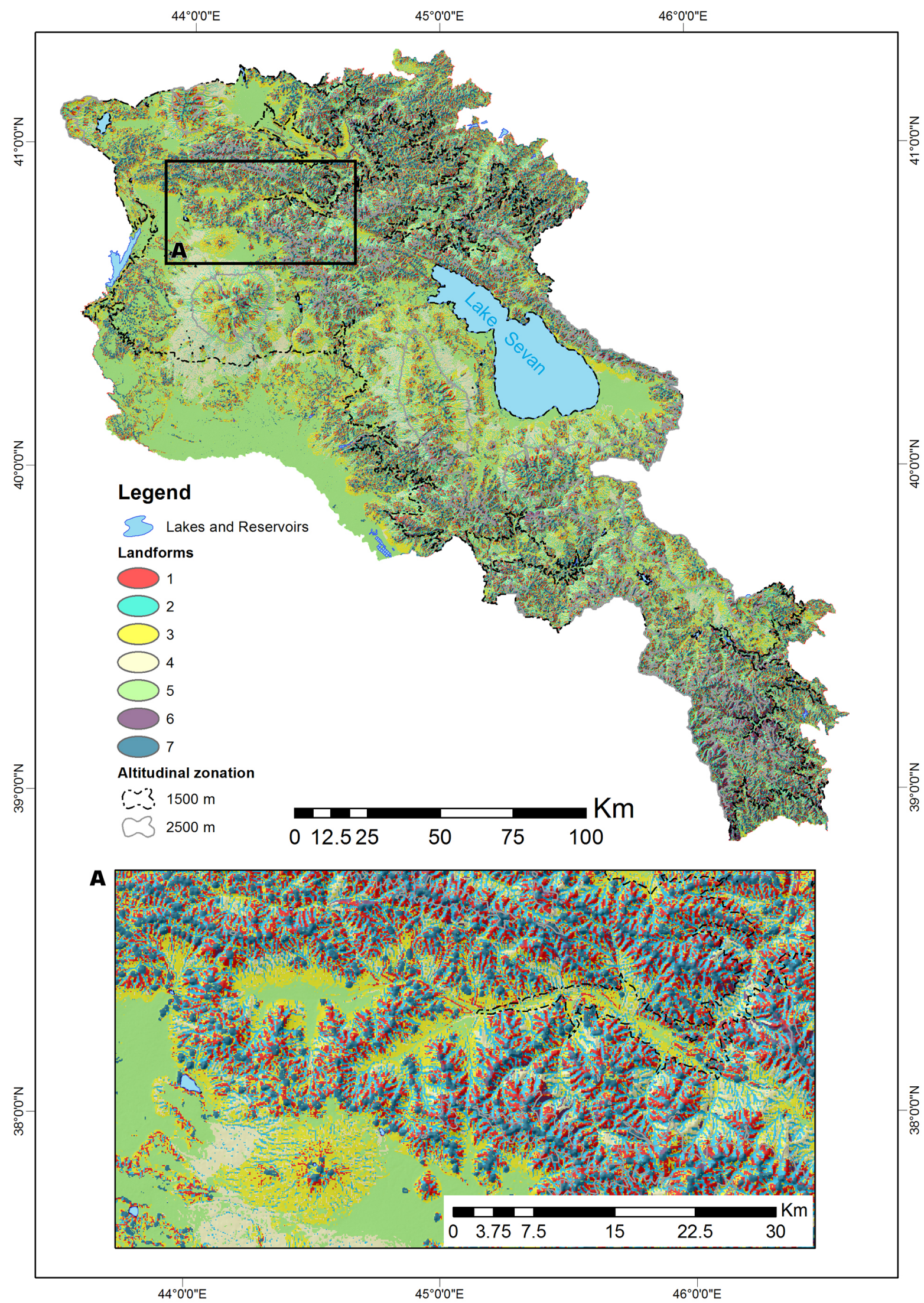

Fig. 5. Map of landforms in Armenia.

1 - "Shoulders", 2 - "Footslopes", 3 - "Backslopes", 4 - "Toeslopes", 5 - "Flat areas", “Floodplains", 6 - "Cliffs", "Steep slopes", 7 - "Summits", "Ridges". 
Table 4. The frequency of the spatial distribution of landforms in the territory of Armenia.

\begin{tabular}{|l|c|c|c|c|}
\hline \multicolumn{1}{|c|}{ Landform element } & Higher Mountain Zone & Middle Mountain Zone & Lower Mountain Zone & All territory \\
\hline Summits, Ridges & 1.67 & 5.18 & 2.20 & 9.05 \\
\hline Shoulders & 3.11 & 9.75 & 4.01 & 16.86 \\
\hline Footslopes & 3.82 & 14.29 & 5.99 & 24.10 \\
\hline Backslopes & 3.35 & 12.04 & 5.35 & 20.74 \\
\hline Toeslopes, & 1.66 & 7.41 & 2.22 & 11.29 \\
\hline Cliffs, Steep slopes & 0.61 & 1.41 & 0.61 & 2.64 \\
\hline Flat areas, Floodplains & 0.25 & 6.99 & 8.08 & 15.32 \\
\hline Total & 14.47 & 57.07 & 28.46 & 100.00 \\
\hline
\end{tabular}

in the Zones of Northern and Southern Foldblock Ranges and are expressed as slopes of large canyons and gorges.

"Flat areas" (except the Middle Araks Depression) are common in The Volcanic Highland, where they are represented as floors of intermountain valleys, volcanic plateaus, river floodplains and large erosional terraces.

\section{Discussions and Conclusions}

Combination of the classification criterias of Dikau (1989), and Dragut, Blaschke (2006) was used to create a map of Armenia with seven landform classes using k-means landform classification algorithm in the Whitebox GAT software. However, the number of classes can be modified, based on study area characteristics and research objectives.

The results show that it is possible to derive landforms for mountain regions based on geomorphometric parameters using a relatively simple algorithm. The advantage of the algorithm is that it requires a relatively limited set of parameters, which are directly related to landform features (Table 3). Finally, automated and semi-automated landform classification methodologies are important parts for many ecological applications, soil resource modelling, landslide hazards, sea-floor and coastal geomorphology (Dragut, Blaschke 2006). Taking into account the very complicated and mountainous characteristics of the topolography of Armenia we argue that this methodology can be important in applications dedicated to disaster risk assessment and management.

Automated and semi-automated methods of landform classification based on GIS and Remote Sensing technologies using geomorphometric parameters in scientific environments started over 25 years ago, but this is the first attempt for the territory of Armenia or parts. Therefore, it cannot be without the obvious and not obvious drawbacks. First of all it is worth mentioning that results accuracy assessment was not carried out based on ground truthing data and auxiliary aerial images for the results of this study. It is important to note that in the case of classification of k-means no object is left unclassified. This is achieved through overlapping every pixel in case study in such a way, that as a result of this classification, each point belongs to only one k cluster. Still, the accuracy assessment in a classification is crucial, and we believe that it will be performed at further stages of study. At this stage, the main purpose was to test one of the existing methods for landform classification of the territory of Armenia and evaluate its behaviour in a territory with such heterogeneous terrain.

\section{References}

Adediran A.O., Parcharidis I., Poscolieri M., Pavlopoulos K., 2004. Computer-assisted discrimination of morphological units on north-central Crete (Greece) by applying multivariate statistics to local relief gradients. Geomorphology 58: 357-370. DOI: 10.1016/j.geomorph.2003.07.024.

Arakelyan A.A., Piloyan A.S., 2011. Identification and delineation of water bodies at Risk by qualitative and quantitative characteristics on example of Aghstev River Basin. Proceedings of the NAS of the Republic of Armenia - Earth Sciences 64(2): 54-64.

Avagyan A.A., Piloyan A.S., Yeritsian H.H., 2010. On Elevation Characteristics and Methodology of its Calculations of Terrain of the Republic of Armenia Based on 1:200000 Scale Digital Elevation Models. Proceedings of the NAS of the Republic of Armenia - Earth Sciences 63(3): 48-58.

Balyan S.P., 1969. Structural geomorphology of Armenian Highland and nearly territories. Geomorphology of the Armenian SSR. Yerevan University Press, Yerevan.

Bates P.D., Anderson M.G., Horrit M., 1998. Terrain information in geomorphological models: stability, resolution and sensitivity. In: Lane, S., Richards, K., Chandler, J. (eds), Landform Monitoring, Modelling and Analysis. Wiley, Chichester: 279-309. 
Berry P.A.M., Garlick J.D., Smith R.G., 2007. Near-global validation of the SRTM DEM using satellite radar altimetry. Remote Sensing of Environment 106(1): 17-27. DOI: 10.1016/j.rse.2006.07.011.

Bezdek C.J., 1981. Pattern Recognition with Fuzzy Objective Function Algorithms. Plenum Press, New York.

Blumberg D.G., 2006. Analysis of large aeolian (wind-blown) bedforms using the Shuttle Radar Topography Mission (SRTM) digital elevation data. Remote Sensing of Environment 100: 179-189. DOI: 10.1016/j.rse.2005.10.011.

Boynagryan V. R., 2007. Slopes and slope processes at the Armenian Highlands. YSU Press, Yerevan.

Brown D.G., Lusch D.P., Duda K.A., 1998. Supervised classification of types of glaciated landscapes using digital elevation data. Geomorphology 21: 233-250. DOI: 10.1016/ S0169-555X(97)00063-9.

Burrough P.A., McDonnell R.A., 1998. Principles of Geographical Information Systems. Oxford University Press, Oxford.

Burrough P.A., van Gaans P.F.M., MacMillan R.A., 2000 High-resolution landform classification using fuzzy k-means. Fuzzy Sets and Systems 113: 37-52. DOI: 10.1016/ S0165-0114(99)00011-1.

Burrough P.A., Wilson J.P., van Gaans P.F.M., Hansen A.J., 2001. Fuzzy k-means classification of topo-climate data as an aid to forest mapping in the greater Yellowstone area, USA. Landscape Ecology 16: 523-546. DOI: 10.1023/ A:1013167712622.

Butler D., 2001. Geomorphic process-disturbance corridors: a variation on a principle of landscape ecology. Progress in Physical Geography 25: 237-248. DOI: 10.1177/030913330102500204.

Chang C.T., Lai J.Z.C., Jeng M.D., 2011. A Fuzzy K-means Clustering Algorithm Using Cluster Center Displacement. Journal of Information Science and Engineering 27(3): 995-1009.

Crevenna A.B., Vicente T.R., Valentino S., Frame D., Ortiz M.A., 2005. Geomorphometric analysis for characterizing landforms in Morelos State, Mexico. Geomorphology 67: 407-422. DOI: 10.1016/j.geomorph.2004.11.007.

Crippen R.E., Hook S.J., Fielding E.J., 2007. Nighttime ASTER thermal imagery as an elevation surrogate for filling SRTM DEM voids. Geophysical Research Letters 34(1): L01302. DOI: 10.1029/2006GL028496.

Dalrymple J.B., Blong R.J., Conacher A.J., 1968. A hypothetical nine unit land surface model. Zeitschrift für Geomorphologie 12: 60-76.

De Bruin S., Stein A., 1998. Soil-landscape modelling using fuzzy c-means clustering of attribute data derived from a Digital Elevation Model (DEM). Geoderma 83: 17-33. DOI: 10.1016/S0016-7061(97)00143-2.

Dehn M., Gärtner H., Dikau R., 2001. Principles of semantic modeling of landform structures. Computers and Geosciences 27: 1005-1010. DOI: 10.1016/S0098-3004(00)00138-2.

Dikau R., 1989. The application of a digital relief model to landform analysis in geomorphology. In: Raper, J. (eds), Three Dimensional Applications in Geographical Information Systems. Taylor \& Francis, London: 51-77.

Dragut L., Blaschke T., 2006. Automated classification of landform elements using object-based image analysis. Geomorphology 81: 330-344. DOI: 10.1016/j.geomorph.2006.04.013

Dragut L., Eisank C., 2012. Automated object-based classification of topography from SRTM data. Geomorphology 141-142: 21-33. DOI: 10.1016/j.geomorph.2011.12.001.
Evans, S., 1972. General Geomorphometry, Derivatives of Altitude, and Descriptive Statistics. In: Chorley R.J. (eds), Spatial Analysis in Geomorphology. Methuen \& Co. Ltd., London: 17-90.

Ehsani A.H., Quiel F., 2008. Geomorphometric feature analysis using morphometric parameterization and artificial neural networks. Geomorphology 99: 1-12. DOI: 10.1016/j. geomorph.2007.10.002.

Falorni G., Teles V., Vivoni V., Bras E.R., Amaratunga K., 2005. Analysis and characterization of the vertical accuracy of digital elevation models from the shuttle radar topography mission. Journal of Geophysical Research 110: F0205. DOI: 10.1029/2003JF000113.

Farr T.G., et al., 2007. The shuttle radar topography mission. Reviews of Geophysics 45(2005): 1-33.

Forman R.T., 1995. Land Mosaics. The Ecology of Landscape and Regions. Cambridge University Press, Cambridge.

Gevorgyan F., Poghosyan D., 1970. On some results of morphometric mapping of the territory the Armenian SSR. Proceedings of NAS Arm. SSR 23(4): 16-24.

Gordon J.E., Brazier V., Lees, G., 1994. Geomorphological systems: developing fundamental principles for sustainable landscape management. In: o'Halloran, D., Green, C., Harley, M., Stanley, M., Knill, J. (eds), Geological landscape conservation. Geological Society, London: 185-189

Grohmann C.H., Riccomini C., Alves F.M., 2006. SRTMbased morphotectonic analysis of the Pocos de Caldas Alkaline Massif, southeastern Brazil. Computers and Geosciences 33: 10-19. DOI: 10.1016/j.cageo.2006.05.002.

Hayakawa Y. S., Oguchi T., Lin Z., 2008. Comparison of new and existing global digital elevation models: ASTER G-DEM and SRTM-3. Geophysical Research Letters 35(17): L17404. DOI: 10.1029/2008GL035036.

Hengl T., Rossiter D.G., 2003. Supervised landform classification to enhance and replace photo-interpretation in semi-detailed soil survey. Soil Science Society of America Journal 67: 1810-1822. DOI: 10.2136/sssaj2003.1810.

Horton R.E., 1945. Erosional Development of Streams and their Drainage Basins, Hydrophysical Approach to Quantitative Morphology. Bulletin of the Geological Society of America 56: 275-330.

Hubbard B.E., Sheridan M.F., Carrasco-Núñez G., Díaz-Castellón R., Rodríguez S.R., 2007. Comparative lahar hazard mapping at Volcan Citlaltépetl, Mexico using SRTM, ASTER and DTED-1 digital topographic data. Journal of Volcanology and Geothermal Research, 160: 99-124. DOI: 10.1016/j.jvolgeores.2006.09.005

Huggel C., Schneider D., Julio Miranda P., Delgado Granados H., Kääb A. Evaluation of ASTER and SRTM DEM data for lahar modeling: a case study on lahars from Popocatépetl Volcano, Mexico. Journal of Volcanology and Geothermal Research 170(1): 99-110. DOI: 10.1016/j.jvolgeores.2007.09.005.

Hunsaker C.T., Levine A., Timmins S.P., Jackson B.L., O'Neill R.V., 1992. Landscape characterization for assessing regional water quality. In: McKenzie, D.H., Hyatt, D.E., McDonald, V.J. (eds), Ecological Indicators. Elsevier, New York: 997-1006.

Irvin B.J., Ventura S.J., Slater B.K., 1997. Fuzzy and isodata classification of landform elements from digital terrain data in Pleasant Valley, Wisconsin. Geoderma 77: 137-154. DOI: 10.1016/S0016-7061(97)00019-0.

Isachenko A.G., 1991. Landscape study and physical and geographical divisions into regions. Visshaya Shkola, Moscow. 
Iwahashi J., Pike R.J., 2007. Automated classifications of topography from DEMs by an unsupervised nested-means algorithm and a three-part geometric signature. Geomorphology 86: 409-440. DOI: 10.1016/j.geomorph.2006.09.012.

Kellndorfer J., Walker W., Pierce C., Dobson D., Fites J.A., Hunsaker C., Vona, J., Clutter, M., 2004. Vegetation height estimation from shuttle radar topography mission and national elevation datasets. Remote Sensing of Environment 93: 339-358. DOI: 10.1016/j.rse.2004.07.017.

Lastochkin A.N., 1991. Relief of the earth surface (Principles and methods of static geomorphology). Nedra, Leningrad.

Lloyd S.P., 1957. Least squares quantization in PCM. Bell Telephone Laboratories Paper.

Lloyd S.P., 1982. Least squares quantization in PCM. IEEE Transactions on Information Theory 28(2): 129-137. DOI: 10.1109/TIT.1982.1056489.

Ludwig R., Schneider P., 2006. Validation of digital elevation models from SRTM X-SAR for applications in hydrologic modeling. ISPRS Journal of Photogrammetry and Remote Sensing 60: 339-358. DOI: 10.1016/j.isprsjprs.2006.05.003.

Lindsay J. B. 2014. The Whitebox Geospatial Analysis Tools project and open-access GIS. In: Proceedings of the GIS Research UK 22nd Annual Conference, The University of Glasgow, 16-18 April. DOI: 10.13140/RG.2.1.1010.8962

MacMillan R.A., Pettapiece W.W., Nolan S.C., Goddard T.W., 2000. A generic procedure for automatically segmenting landforms into landform elements using DEMs, heuristic rules and fuzzy logic. Fuzzy Sets and Systems 113: 81-109. DOI: 10.1016/S0165-0114(99)00014-7.

MacMillan R.A., Shary P.A., 2009. Landforms and landform elements in geomorphometry. Developments in soil science 33: 227-254. DOI: 10.1016/S0166-2481(08)00009-3.

MacQueen J., 1967. Some methods for classification and analysis of multivariate observations. In: Proc. 5th Berkeley Symp. on Math. Statistics and Probability: 281-297.

Mitasova H., Hofierka J., 1993. Interpolation by regularized spline with tension: II. Application to terrain modeling and surface geometry analysis. Mathematical Geology 25(6): 657-669. DOI: 10.1007/BF00893172.

Moravej K., Karimian Eghbal M., Toomanian N., Shahla Mahmoodi S., 2012. Comparison of automated and manual landform delineation in semi detailed soil survey procedure. African Journal of Agricultural Research 17(7): 2592-2600. DOI: 10.5897/AJAR11.728.

Orhan U., Hekim M., Ibrikci T., 2008. Gravitational fuzzy clustering. Lecture Notes in Artificial Intelligence 5317: 524531. DOI: $10.1007 / 978-3-540-88636-5 \_50$.

Pennock D.J., Zebarth B.J., de Jong E., 1987. Landform classification and soil distribution in hummocky terrain. Geoderma 40(3-4): 297-315. DOI: 10.1016/0016-7061(87)90040-1.

Piloyan A., Avagyan, A. 2016. The Circular Structures of the Republic of Armenia Based on a Digital Elevation Model. European Journal of Geography 7(3): 57-69.

Prima O.D.A., Echigo A., Yokoyama R., Yoshida T., 2006. Supervised landform classification of Northeast Honshu from DEM-derived thematic maps. Geomorphology 78: 373-386. DOI: 10.1016/j.geomorph.2006.02.005.

Rabus B., Eineder M., Roth A., Bamler R., 2003. The shuttle radar topography mission - a new class of digital eleva- tion models acquired by spaceborne radar. ISPRS Journal of Photogrammetry and Remote Sensing 57: 241-262. DOI: 10.1016/S0924-2716(02)00124-7

Rodriguez E., Morris C., Belz J., Chapin E., Martin J., Daffer W., Hensley S., 2005. An assessment of the SRTM topographic products. In: Technical Report JPL D-31639. Jet Propulsion Laboratory. Pasadena, California.

Schillaci C., Braun A., Kropáček J. Terrain analysis and landform recognition. In: Clarke L., Nield J. (eds), Geomorphological Techniques. British Society for Geomorphology: 1-18. DOI: 10.13140/RG.2.1.3895.2802.

Shary P.A, 1995. Land surface in gravity points classification by a complete system of curvatures. Mathematical Geology 27: 373-390. DOI: 10.1007/BF02084608

Shary P.A., Sharaya L.S., Mitusov A.V., 2002. Fundamental quantitative methods of land surface analysis. Geoderma 107: 1-32. DOI: 10.1016/S0016-7061(01)00136-7

Schmidt J. Hewitt A., 2004. Fuzzy land element classification from DTMs based on geometry and terrain position. Geoderma 121: 243-256. DOI:10.1016/j.geoderma.2003.10.008.

Simonov Yu. G., 1999. The explanatory morphometry of the relief. GEOS, Moscow.

Steinhaus H., 1956. Sur la division des corps materiels en parties. Bull. Acad. Polon. Sci. 6: 801-804.

Stepinski T.F., Vilalta R., 2005. Digital topography models for Martian surfaces. IEEE Geoscience and Remote Sensing Letters 2(3): 260-264. DOI: 10.1109/LGRS.2005.848509.

Stevens N.F., Garbeil H., Mouginis-Mark P.J., 2004. NASA EOS Terra ASTER: Volcanic topographic mapping and capability. Remote Sensing of Environment 90: 405-414. DOI: 10.1016/j.rse.2004.01.012.

Townshend J.R.G., 1981. Terrain Analysis and Remote Sensing. George Allen and Unwin, London.

Turner M.G., 1990. Spatial and temporal analysis of landscape pattern. Landscape Ecology 4(1): 21-30. DOI: 10.1007/BF02573948.

Ventura S., Irvin B., 2000. Automated Landform Classification Methods for Soil Landscape Studies. In: Wilson J.P., Gallant J.C. (eds.), Terrain Analysis Principals and Applications. John Wiley and Sons, New York: 245-294.

Vriend S.P., van Gaans P.F.M., Middelburg J., de Nijs A., 1988. The application of fuzzy c-means cluster analysis and non-linear mapping to geochemical datasets: examples from Portugal. Applied Geochemistry 3(2): 213-224. DOI: 10.1016/0883-2927(88)90009-1.

Wood J., 1996. The Geomorphological Characterisation of Digital Elevation Models. Ph.D. Thesis. University of Leicester, England. Online: https://lra.le.ac.uk/handle/2381/34503 (accessed 23 April 2016)

Wright R., Garbeil H., Baloga S.M., Mouginis-Mark P.J., 2006. An assessment of shuttle radar topography mission digital elevation data for studies of volcano morphology. Remote Sensing of Environment 105(1): 41-53. DOI: 10.1016/j. rse.2006.06.002.

Zavoianu I., Cruceru N., Heritanu G., 2013. Morphometry elements of hydrographic basins with use in the characterization of relief. Revista de Geomorfologie 15: 89-98.

Zohrabyan L.N., 1979. Orography of the Armenian Highland (experiment in orographical analysis of morphostructure). Arm. SSR NAS Press, Yerevan. 